\title{
INFORMATION NEEDS AND SEEKING BEHAVIOUR AMONG URBAN FARMERS IN KWARA STATE, NIGERIA
}

\author{
Ogunlade, I.* Oladele, O.I.* and Falaki A.A.** \\ * Department of Agricultural Extension and Rural Development \\ University of Ilorin, Nigeria
}

\section{Department of Agricultural Extension and Rural Development University of Ibadan, Nigeria}

\begin{abstract}
This study examined the socio-economic characteristics of people involved in urban farming, their information needs and seeking behaviour. The study area was Ilorin metropolis in Kwara state. A structured questionnaire was used to elicit information from 100 urban farmers. Purposive sampling technique was used in selecting the respondents and the data collected were analyzed by the use of descriptive and inferential statistical tools. The study showed that urban farming was a supplementary activity practiced by people with high literacy level Their mean age was 47 years and mean income from their main occupation was $\$ 22,000$. The farms are mainly located within the city with more farmers practicing animal production than crop production. People turned to urban farming practice as a coping mechanism to survive the economic hardship of the urban center. The study concluded that urban farming had some unique features and has impact on the social and economic life of its practitioners. However, it suggested that urban farmers could produce better result if the necessary technical and financial impetus was provided. It was recommended that government should give official recognition to urban farming and pay attention to it through relevant existing agencies. The roles to be played by agricultural extension service providers were also mentioned.
\end{abstract}

\section{Introduction}

The current emphasis by national governments and international development agencies on urban agriculture and the problems of food security, population growth, poverty and all its associated problems in developing countries makes this research a timely one. Many decision makers continue to regard rural as synonymous with agriculture, despite the fact that $30 \%$ of the economically active rural population in Latin America is nowadays engaged in non-agric activities as their main occupation. Almost $50 \%$ of all gainfully employed women between the ages of 15 and 44 years work in the off-farm sector. The share for men is around $30 \%$ $40 \%$. These off farming activities of the rural areas account for some $40 \%$ of total income in rural areas (Driven, 2001). This situation is similar in Nigeria, where people, both old and young, are turning from agricultural activities to non-farming activities in the rural areas. Similarly, more urban dwellers are today engaged in agricultural activities to meet their survival needs. 
While agriculture is largely rural based, it is known that some farming do take place in and around most cities of the world. Such practice is termed Urban Agriculture or City Farming. Urban Agriculture in its simplest form ranges from growing crops on roof tops to raising livestock in backyards and raising fish in ponds, streams and lagoons. An estimated 800 million people worldwide practice it, and this number is expected to grow steadily in the next century, particularly, in the developing countries where rapid urbanization is under way (Konukiewitz, 2001). Urban agriculture takes place in all regions of the world both developed and developing countries, but it is most prevalent in Asia.

Urban agriculture is helping to lift hundreds of million of people out of extreme poverty and improves the health and nutrition of city dwellers across the globe. Urban agriculture is also boosting the economies, enhancing the environment, strengthening food supplies of cities in both developed and developing countries, and is becoming a prime source of income for the swelling population of world cities. The average annual population increase in the urban areas of developing countries during the first decade of the new millennium was projected to be about 64 million. During the 2020 's, it is projected that some 77 million persons will be added to the world urban population each year, the bulk of this growth, some 74 million, will occur in developing countries (Hundsalz, 2001).

Agricultural goods produced in cities are the corner stone of many urban economies. Urban industries especially the engineering and chemical industries - developed the pre-requisite for improving productivity in agriculture, which has led to a situation where, nowadays, less than $5 \%$ of the working population produces more than enough food whereas in preindustrial times it took more than $50 \%$ of the working population to produce as much (Konukiewitz 2001). To meet the agricultural needs of the fast increasing population the world over, there is a need for an increased productivity of the system. To achieve this, there is a need to do an analysis of urban farming, showing who the practitioners are, why they are engaged in it, their sources of information, information needs, and means that will help agricultural extension services bring the improved knowledge and technology of farming to the doorsteps of the farmers. The peculiarities of urban farming must be brought to the fore thereby enabling policy makers formulate informed and meaningful policies towards the development of urban farming.

Besides Asia, since the late 1970s, city farming has been growing in many developed and deveioping countries, in terms of the number of people involved, area, used, and benefits realized by households and city economies as well as new challenges. According to Mougeot (1994), in the 
early 1990 s, nearly 2500 community gardening sites were found in nine major North American cities. Survey evidences in Latin America have also revealed a growing and diversifying range of official activities in city farming in the Dominican Republic, Mexico, Costa Rica, Peru and Argentina Local authorities have been reversing long held negative attitudes towards city farming and developing sustainable urban farming policies. More governments are creating agencies and programs to promote and manage city farming.

Many African nations are currently moving from the negative notion on city farming to officially embrace its over-riding advantages. This move is exemplified in the design of new capital cities of Coted'voire, Malawi and Tanzania and also expressed in the master plans of Kinshasa, Maseru and Kampala and in the urban management of Dar es Salaam. Economic structural adjustment programmes and the collapse of much of the formal economy have stimulated the expansion of urban farming in Africa (Spore 1991, 1999). In the post structural adjustment programme era, many of the cities no longer have the wherewithal to sustain the ever increasing influx of youth population into cities (Ladele 1998). As a reaction to coping with the growing trend in urban poverty, hardly is there any city totally exempted from the practice of urban agriculture. What varies are probably the scope, official stance and challenges facing the urban farmers.

The trend in city farming in Nigerian cities is on the increase and has largely been considered part of the informal sector but has not been the subject of much scientific study. Urban agriculture is now capturing growing attention among international bodies. After the survey of the practice in the pacific basin, IDRC held a seminar in Singapore and started a worldwide literature search in 1984. In the late 1980s, UNDP implemented various projects and IDRC funded four studies in Kenya, Uganda and Tarizania. By 1988, United Nations University's Food Energy Nexus programme had published a series of research reports in selected regions, countries and cities. Building on this, UNDP's Urban Agriculture Network (TUAN) surveyed twenty-one countries in 1991-1992 and stimulated interested agencies to effectively promote urban agriculture development including waste water farming (IDRC 1993). In Nigeria, urban agriculture has been expanding in many cities since the early $1950 \mathrm{~s}$. According to IDRC (1993) a number of factors are responsible for this phenomenon. These factors include: rapid urbanization, crippled food distribution systems, withdrawal of subsides, reduction of wages, inflation, unemployment, ineffective agricultural policies and urban tax regulations. Gbadegesin (1991) cited another reason for the new interest in urban agriculture as the inability of the rural farmer to cope with the food demand in the country because of the conflict of interests between the cultivation of 
food crops and cash crop that yield more income. Hence, the rural farmer only grows food crops for his own subsistence, thereby causing shortage for the large population in the cities.

\section{Statement of Research Problem}

Due to the increase in rural urban migration, farming is being left in the hands of a few rural dwellers who are mostly children and aged people lacking the necessary factors of production to increase food supply. As a result, Nigeria has been witnessing shortage or scarcity of food. Accessibility to adequate food supply, constitutes a serious problem for many Nigeria households today. It has reached an alarming rate that is approaching a food crises situation. Food prices have soared in the last two decades, especially since the end of the civil war. Food price inflation constitute the greatest threat to the living standard of Nigerian families as food prices continue to increase almost on a daily bases. In 1994, the urban consumer price index for food was 1,282.40 and rose by $109 \%$ to $2,680.10$ in 1996. This figure rose to 2,944.10 in 1998 making an overall increase of $130 \%$ from 1994 to 1998 (CBN 1998).

This is caused mainly by supply not being able to meet the ever increasing demand of the population, thereby removing some food from the dining tables of many families. The salary earners appear worse-off as the high inflation rates have made a complete mess of the various increments in the salaries of workers given by both the Federal and State governments. Many workers spend over three quarters of their take home pay on food, leaving the remaining one quarter to take care of other needs.

Most studies on agriculture naturally focus on the rural areas. While it is true that agriculture is largely rural based, not paying attention to urban agriculture is likely to be counter productive because the special features of city farming are quite distinct from those of rural farming. This poor attention notwithstanding, household gardens and small animal production are popular self help ways for households to improve their food security in the study area. Because governments have often failed to nurture urban agriculture or to understand how it works, its economic potentials remain largely untapped and demands urgent intervention. This calls for more empirical information that may assist planners in policy decision making. It is in view of this that this study revolves around the analysis of urban agriculture in the study area. This research was intended among other things, to provide answers to the following questions:

i. Who are those engaged in urban agriculture?

ii. What type of urban agriculture do they practice?

iii. What are the motives behind their practice of urban agriculture?

iv. What information seeking behaviour do urban farmers have? 
v: What are the problems facing urban agriculture?

\section{Objectives of the Study}

The general objectives of this study was to investigate urban agriculture in the Ilorin Metropolis, Kwara State. The specific objectives were as follows:

i. To evaluate some socio-economic characteristics of those engaged in urban agriculture.

ii. To determine the motives behind urban agriculture

iii. To identify the information sources of urban farmers

iv. To identify the problems facing urban agriculture

\section{Methodology}

Ilorin, the Kwara state capital, was chosen for this study because of Kwara State's potential for agricultural production in general and the popularity of urban agriculture within and around the Ilorin metropolis in particular. Kwara State is situated between latitude $7^{\circ} 20^{\prime}$ and $11^{\circ} 05^{\prime}$ north of the equator and between longitude 205 and 6045 east of the prime meridian. It is within the North Central geo-political zone of Nigeria. It is bounded to the north mainly by Niger state, in the south by Oyo, Osun and Ekiti states, in the west by Benin Republic and the east by Kogi state. It presently consist of 16 local government areas. Kwara state was created on $29^{\text {th }}$ May 1967.

It has a population of 1.57 million, with Ilorin having 572,178 (census 1991), and a land area of about 32,500 square kilometers. Ilorin spreads over three local government areas, llorin East, Ilorin West and Ilorin South. (Kwara Diary, 2000). According to Kwara Agricultural Development Agency in its impact study report for 1989-1993, 75\% of Kwara state population lives in the rural areas. Over $90 \%$ of the rural population engages in various forms and sizes of agricultural activities. Four main ethnic groups, namely, Yoruba, Baruba, Nupe and Fulani are found in the state. Ilorin is also the home of three national agricultural institutes; Agricultural and Rural Management training Institute (ARMTI), National Center for Agricultural Mechanization (NCAM), and Nigeria Stored Products Research Institute (NSPRI).

The study population comprise of urban agriculture practitioners within the study area while the sample size is one hundred (100) of such urban agriculture practitioners. Purposive sampling technique was used to select the respondents from the following areas of Ilorin metropolis. Adewole Estate, Taiwo/Unity Road, Tanke, Fate/Basin, and GRA. Twenty (20) questionnaires were administered in each of these areas. These areas are characterized by less traditional life style, medium to low population density, planned/fairly planned residential areas with modern houses, 
improved living standards and mainly inhabited by non-indigenous of Ilorin. Government offices are common in these areas. Social amenities and infrastructures are also available. Descriptive statistics such as percentages, means, frequency counts, and mean ratings, were used in analyzing the data.

\section{Results and Discussion}

The socio-economic characteristics are vital for gaining insight into the kind of persons involved in urban farming. Table 1 shows that $71 \%$ of the respondents were males while $29 \%$ were females. The mean age was 47 years. Youths, aged 30 years and below make up $10 \%$ of the urban farmers. While the middle aged, within the age range of $31-50$ years make up $58 \%$. On marital status, majority were married $(84 \%)$ while $11 \%$ were single. The mean household size was 6 , with $65 \%$ of the urban farmers having a household size of between 5 and 8 people.

Table 1 Distribution of Respondents by sex, marital status and household size

\begin{tabular}{|lcc|}
\hline Characteristics & Frequency & Percentage \\
\hline Sex: & & 71 \\
\hline Male & 71 & 29 \\
\hline Female & 29 & 100 \\
\hline Total & 100 & \\
\hline Age (Group) & 10 & 10 \\
\hline Youth & 58 & 58 \\
\hline Middle- Aged & 32 & 32 \\
\hline Aged & 100 & 100 \\
\hline Total & & \\
\hline Marital Status: & 11 & 11 \\
\hline Single & 84 & 84 \\
\hline Married & 4 & 4 \\
\hline Widowed & 1 & 1 \\
\hline Divorced & 100 & 100 \\
\hline Total & & 28 \\
\hline Size of Household: & 28 & 65 \\
\hline $1-4$ & 65 & 7 \\
\hline $5-8$ & 7 & 100 \\
\hline 9 and above & 100 & \\
\hline Total & & \\
\hline
\end{tabular}


The educational qualification of the respondents as shown in Table 2 reveals that contrary to the common situation in the rural areas, urban farmers are predominantly literate, with $75 \%$ of them having postsecondary education and $20 \%$ secondary education. Majority of the respondents were into urban farming on part-time basis. The main occupation of urban farmers comprise of civil servants $(43 \%)$, artisans $(14 \%)$, and traders $(8 \%)$. The remaining $35 \%$ had farming as their main occupation. The mean monthly income from the main occupation of the respondents was $\mathrm{N} 22,000.00$. Those earning $\mathrm{N} 20,000.00$ and below were $47 \%$, those earning between $\mathrm{N} 21,000$ and $\mathrm{N} 40,000$ were $33 \%$ and those earning $\mathrm{N} 41,000$ and above were $20 \%$.

Table 2 Respondents' educational qualification, occupation and average monthly income

\begin{tabular}{|c|c|c|}
\hline Characteristics & Frequency & Percentage \\
\hline \multicolumn{3}{|c|}{ Educational Qualification: } \\
\hline No formal Education & 2 & 2 \\
\hline Primary Education & 3 & 3 \\
\hline Secondary Education & 20 & 20 \\
\hline Total & 100 & 100 \\
\hline \multicolumn{3}{|l|}{ Occupation } \\
\hline Civil servant & 43 & 43 \\
\hline Farming & 35 & 35 \\
\hline Trading & 8 & 8 \\
\hline Artisan & 14 & 14 \\
\hline Total & 100 & 100 \\
\hline \multicolumn{3}{|c|}{ Average Monthly Income (N) from main occupation } \\
\hline 20,000 and below & 47 & 47 \\
\hline $21,000-40,000$ & 33 & 33 \\
\hline 41,000 and above & 20 & 20 \\
\hline Total & 100 & 100 \\
\hline
\end{tabular}

From Table 3, the mean years of residence in the city was 24 years, $11 \%$ had lived in the city for between 1 and 10 years and 15\% for 31 years and above. The mean years of involvement in urban farming was 9 years and $59 \%$ were still within 10 years of urban farming while $4 \%$ had put 31 years and above into it. For the source of farm labor, $65 \%$ of the respondents use both family and hired labour while $28 \%$ use only family labor. The remaining $7 \%$ use only hired labor. The high literacy level of urban farmers 
in this study is an important factor that they can take advantage of in the process of improving their knowledge of farm practices and production level. The fact that majority of the respondents had a primary occupation probably indicate that urban farming was largely a supplementary activity. Large households may translate into increased farm labor. This supports Dennary (1997), who reported that city dwellers who work and own a farm fare better than their counterparts who relied mostly on their salaries. This according to him, is because the salary money may not be forth coming, but they could still sustain their family on the various produce from their farming activities.

The high occurrence of urban farming among middle and low-income earners may suggest that just it is a vital poverty alleviation and survival strategy in the city. The high income earners involved in urban farming may be involved in it just as a.hobby or to optimize available resources. The trend in the years of residence in the city and the years of practice of urban farming shows that urban farming is becoming increasingly popular, especially in recent years. This may not be unconnected with the increasing poverty and economic hardship in the city.

Table 3 Distribution of Respondents by length or residence, urban farming experience and sources of farm labour

\begin{tabular}{|lll|}
\hline Characteristics & Frequency & Percentage \\
\hline Years of Residence in the city: & 11 & 11 \\
\hline $1-10$ & 34 & 34 \\
\hline $11-20$ & 40 & 40 \\
\hline $21-30$ & 15 & 15 \\
\hline 31 and above & 100 & 100 \\
\hline Total & & \\
\hline Years of Practice of Urban farming & 59 & 59 \\
\hline $1-10$ & 31 & 31 \\
\hline $11-20$ & 6 & 6 \\
\hline $21-30$ & 4 & 4 \\
\hline 31 and above & 100 & 100 \\
\hline Total & & \\
\hline Sources of farm labour. & 28 & 28 \\
\hline Family & 7 & 7 \\
\hline Hired & 65 & 65 \\
\hline Both & 100 & 100 \\
\hline Total & \\
\hline
\end{tabular}


From Table 4, personal experience was found to be the major source of information used by the urban farmers with a mean rating of 2.8 which is closer to the score for major source than the score for minor source. Friends and the print media constitute minor sources of information with mean ratings of 1.9 and 1.5 respectively, which are closer to the score for minor source than the score for not a source. Extension agents, agricultural cooperative societies, agro-shows, electronic media and the Internet were the least used as sources of information by the urban farmers, going by their mean ratings which are closer to the score for not a source than minor sources. It might be implied from this that urban farmers' dependence on personal experience, friends and print media as their sources of information might have limited their knowledge of improved farm practices which, if applied, could improve their production.

Table 4: Information sources used by the Urban Farmers

\begin{tabular}{|l|l|l|l|l|l|}
\hline $\begin{array}{l}\text { Sources of } \\
\text { Information }\end{array}$ & $\begin{array}{l}\text { Major } \\
\text { source }\end{array}$ & $\begin{array}{l}\text { Minor } \\
\text { source }\end{array}$ & $\begin{array}{l}\text { Not a } \\
\text { source }\end{array}$ & $\begin{array}{l}\text { Mean } \\
\text { Rating }\end{array}$ & Ranking \\
\hline Experience & 78 & 19 & 3 & 2.8 & 1 \\
\hline Friends & 21 & 49 & 30 & 1.9 & 2 \\
\hline Print Media & 8 & 30 & 62 & 1.5 & 3 \\
\hline $\begin{array}{l}\text { Agric. } \\
\text { Show/Workshop }\end{array}$ & 11 & 18 & 71 & 1.4 & 4 \\
\hline Agro-shops & 3 & 30 & 67 & 1.4 & 4 \\
\hline ADP/MANR & 6 & 24 & 70 & 1.4 & 4 \\
\hline Extension Agent & 4 & 24 & 72 & 1.3 & 7 \\
\hline $\begin{array}{l}\text { Agric. Cooperative } \\
\text { Societies }\end{array}$ & 5 & 16 & 79 & 1.3 & 7 \\
\hline Electronic Media & 1 & 22 & 77 & 1.2 & 9 \\
\hline Internet & 1 & 7 & 92 & 1.1 & 10 \\
\hline
\end{tabular}

*ADP/MANR Agricultural Development Programme/ Ministry of Agriculture and Natural Resources

Table 5 presents the information sources used by the urban farmers. Personal visit was ranked first and as a frequently used method of communication by the farmers with a mean rating of 2.7 which is closer to the score for frequently used than that of not frequently used. A publication was ranked second and group meetings ranked third with mean ratings of 1.7 and 1.6 respectively. This makes them not frequently used because their mean ratings are closer to the score for not frequently used than to that of not used. 
Radio/TV and phone calls were the least used methods of communication with mean ratings of 1.3 and 1.4 respectively, which are closer to the score for not used communication methods than that of not frequently used. The use of personal experience and friends as the major and minor sources of information respectively might have influenced the use of personal visits as a frequently used communication method. The high literacy level of urban farmers might have also influenced the use of publications as a not frequently used method of communication. It should also be noted that the print media ranked next to experience and friends in the sources of information used by the urban farmers.

\section{Table 5: Communication Methods used by Urban Farmers}

\begin{tabular}{|l|l|l|l|l|l|}
\hline $\begin{array}{l}\text { Communication } \\
\text { methods }\end{array}$ & $\begin{array}{l}\text { Frequently } \\
\text { used }\end{array}$ & $\begin{array}{l}\text { Not } \\
\text { frequently } \\
\text { used }\end{array}$ & $\begin{array}{l}\text { Not } \\
\text { used }\end{array}$ & $\begin{array}{l}\text { Mean } \\
\text { rating }\end{array}$ & Ranking \\
\hline Personal visit & 74 & 19 & 7 & 2.7 & 1 \\
\hline Publications & 23 & 19 & 58 & 1.7 & 2 \\
\hline Group meetings & 24 & 14 & 62 & 1.6 & 3 \\
\hline Phone calls & 13 & 11 & 76 & 1.4 & 4 \\
\hline Radio/TV & 6 & 19 & 75 & 1.3 & 5 \\
\hline
\end{tabular}

In Table 6, ADP/MANR were ranked first as the agricultural establishment most frequently visited with a mean rating of 1.8 and Faculty of Agriculture, University of Ilorin followed with a mean rating of 1.6. However, from the mean ratings of these top two agricultural establishments visited, it was observed that urban farmers did not frequently visit these establishments. This is because their mean ratings were closer to the score for not frequent than to the score for frequent.

With the urban farmers' visit to agricultural establishments not frequent, there are possibilities of the farmers not possessing the latest information available on farm practices. It is interesting to note that the highest percentage of the respondents chose their source of information based on easy access to latest/required information. The other agricultural establishments were the least visited, going by their mean ratings which are closer to the score for not visited than to not frequently visited. 
Table 6 Agricultural Establishments as sources of information by Urban Farmers

\begin{tabular}{|l|l|l|l|l|l|}
\hline $\begin{array}{l}\text { Agricultural } \\
\text { Establishment }\end{array}$ & Frequent & $\begin{array}{l}\text { Not } \\
\text { frequent }\end{array}$ & $\begin{array}{l}\text { Not } \\
\text { visited }\end{array}$ & $\begin{array}{l}\text { Mean } \\
\text { rating }\end{array}$ & Ranking \\
\hline ADP/MANR & 28 & 19 & 53 & 1.8 & 1 \\
$\begin{array}{l}\text { Faculty of Agr. } \\
\text { UNILORIN }\end{array}$ & 26 & 11 & 63 & 1.6 & 2 \\
ARMTI & 1 & 20 & 79 & 1.2 & 3 \\
NISPRI & 1 & 8 & 91 & 1.1 & 4 \\
NCAM & 0 & 11 & 89 & 1.1 & 4 \\
$\begin{array}{l}\text { Other private } \\
\text { and govt. } \\
\text { establishments } \\
\text { outside the } \\
\text { state }\end{array}$ & 3 & 4 & 93 & 1.1 & 4 \\
\hline
\end{tabular}

"UNILORIN -- University of Ilorin, ARMTI- Agricultural Research, Management and Training Institute, NISPRI - Nigerian Institute of Stored products Research Institutes and NCAM- National Center for Agricultural Mechanization

From Table 7, major reasons for the choice of the urban farmers' sources of information are easy access to latest/required information $(26.5 \%)$, reliability of information based on experience $(22.8 \%)$ and access to practical knowledge $(21.3 \%)$. These qualities are what they appreciated in a source of agricultural information. The least proportion of respondents was recorded for the information source being the only one known to the farmers. This implies that the respondents were aware of alternative sources of information they could explore.

Table 7: Respondents' reasons and purposes of information seeking from extension agents and agricultural establishments

\begin{tabular}{|l|c|c|}
\hline Information seeking reasons and purposes & Frequency & Percentage \\
\hline Reason for Choice of source of Information: & & \\
Easy access to latest/required information & 56 & 26.5 \\
Easy understanding of information & 29 & 13.7 \\
disseminated & 45 & \\
Access to practical knowledge & 15 & 21.3 \\
That is the only means I know & 7.1 \\
Reliability of information based on experience & 48 & 22.8 \\
Efficiency of source of information & 18 & 8.6 \\
Total & $\mathbf{2 1 1 ^ { * }}$ & $\mathbf{1 0 0}$ \\
\hline
\end{tabular}


Purposes of visit to Agricultural Establishment

Seeking advice

Purchase input

Hire farm implement

Attend workshop/seminar/training

Non-farm purpose

Total

"Multiple responses

In Table 8, farmers ranked how serious the information needs were to them. The top information needs were disease and pest prevention/management, where/how to acquire credit facilities/subsidies, where to purchase agricultural inputs, use of agro-chemicals, marketing of produce, improved cultural practices and storage of produce, in descending order of seriousness.

However, their mean rating shows that none of these information needs was a serious need. This is because their mean ratings were closer to the score for not serious need than to the score for serious need. The remaining information needs are forth coming agricultural events, processing of produce, hiring of agricultural implements and record keeping, in descending order of seriousness. These were the least information needs judging by their mean ratings which are closer to the score for not a need than to not serious need. It is noted that most of the top information needs such as disease/pest prevention/management, access to credit/subsidies, use of agro-chemical, improved cultural practices require high technical/professional contributions for the needs to be met. 
Table 8: Urban Farmers' Information Needs

\begin{tabular}{|l|l|l|l|l|l|}
\hline Information Needs & $\begin{array}{l}\text { Serious } \\
\text { Need }\end{array}$ & $\begin{array}{l}\text { Not } \\
\text { serious } \\
\text { Need }\end{array}$ & $\begin{array}{l}\text { Not } \\
\text { a } \\
\text { need }\end{array}$ & $\begin{array}{l}\text { Mean } \\
\text { Rating }\end{array}$ & Ranking \\
\hline $\begin{array}{l}\text { Disease and Pest } \\
\text { Prevention/Management }\end{array}$ & 56 & 27 & 17 & 2.4 & 1 \\
$\begin{array}{l}\text { Where to Access Credit } \\
\text { Facilities/Subsidies }\end{array}$ & 56 & 19 & 25 & 2.3 & 2 \\
$\begin{array}{l}\text { Where to purchase input } \\
\text { Use of Agro-chemical }\end{array}$ & 18 & 35 & 47 & 1.7 & 3 \\
input cultural & 14 & 30 & 56 & 1.6 & 4 \\
$\begin{array}{l}\text { Marketing of Produce } \\
\text { Improved } \\
\text { practices }\end{array}$ & 16 & 26 & 55 & 1.6 & 4 \\
$\begin{array}{l}\text { Storage of produce } \\
\text { Forthcoming Agricultural }\end{array}$ & 13 & 13 & 62 & 1.5 & 6 \\
$\begin{array}{l}\text { Event Processing of Produce } \\
\text { Proct Agricultural }\end{array}$ & 12 & 13 & 75 & 1.5 & 6 \\
$\begin{array}{l}\text { Hiring of } \\
\text { implement } \\
\text { Record keeping }\end{array}$ & 5 & 13 & 77 & 1.4 & 8 \\
\hline
\end{tabular}

\section{Conclusion}

This study revealed that urban agriculture has a significant impact on the social and economic life of its practitioners in the study area. It also clarified the peculiar nature of the practice and the practitioners. However, there exists some similarities between rural and urban farming in their motives, information sources used, communication methods used, information needs and problems. The busy life in urban centers coupled with the fact that most urban farmers have other occupations, alternative sources of income, high literacy level, awareness of various information sources, and visit to agricultural establishments, are in contrast to the situation of rural farmers.

This study also identified urban farming as a coping mechanism in dealing with poverty and economic hardship which are prevalent in the urban centers. It is also evident, from the study, that urban farming is being starved of the wealth of knowledge and benefit that could have accrued to it through the services of agricultural extension agents. The most pressing information need of the urban farmers being disease/pest prevention/management and access to credit/subsidies require technical assistance. Their most challenging problems are however financially oriented. Urban farmers and urban centers already have attributes such as high literacy level and presence of social infrastructures, which extension 
agents could take advantage of in performing their duties of information dissemination and rendering support services to urban farmers. It is hoped that this will result in increased production, better income and improved standard of living for urban farmers.

\section{References}

CBN (1998). Annual report, Urban consumer price index. 128.

Dirven, M. (2001). "Strategies for Stemming the rural exodus in Latin America" Agriculture and Rural Development 2 (2) Ottawa, 63 65 .

Gbadegesin, A and Olawoye, J. (2000). "Third economy for sustainable livelihoods" _. Paper presented for a workshop organized by NEST and held at NEST house, Ibadan.

Hundsaltz, M. (2001). "Key issues for an integrated policy on integrated development". Agriculture and Rural Development 2 (2), 51-55.

IDRC (1993). International Development Research Center Reports. Farming in cities; the rise of Urban Agriculture. 21 (3), 2-21.

Konukiewitz, M. (2001). "Town: Supplies Everyday Commodities Countryside: Provides Food" Agriculture and Rural Development. 2 (1) $56-58$.

Kwara Diary (2000). Kwara State Government, Ilorin, Kwara State.

Ladele, A.A. (1998). "Strategies to integrate Youths in Agricultural Development in Nigeria.'. Journal of Agriculture and Rural Development.

Ladele, A.A. and Omotesho, O.A. (2000). Some features of city farming in two Nigerian Cities: Ibadan and Ilorin. Proceedings of the Sixth Annual Conference of the Agricultural Extension Society of Nigeria (AESON) 17-21.

Mougeot, L. (1994). "The rise of city farming Research must catch on with reality". ILEIA Journal. 10 (4), 4-5.

Spore (1991). A future employment trend; The urban farmers CTA, 81, 1-2.

Spore (1999). Take your farm to town CTA. 81, 1-2. 
World Bank (1996). Nigeria: Poverty in the midst of plenty: A challenge of growth with inclusion. A World bank Poverty Assessment Report. University of Ibadan, Ibadan. 